\title{
Crop-livestock interactions in agricultural and pastoral systems in West Africa
}

\author{
Mark Moritz
}

Accepted: 24 September 2008/Published online: 10 February 2009

(C) Springer Science+Business Media B.V. 2009

\begin{abstract}
Driven by population pressures on natural resources, peri-urban pastoralists in the Far North Province of Cameroon have recently intensified livestock production in their traditional pastoral system by feeding their cattle cottonseed cakes and other agricultural byproducts to cope with the disappearance of rangelands typically available through the dry season. Although the crop-livestock interactions in this altered intensive pastoral system seem similar to alterations recently named in mixed-farming systems in West Africa, they are distinctly different and would require a different type of agricultural development support. I use Bourdieu's theoretical constructs of "habitus" and "capital" to explain those differences.
\end{abstract}

Keywords Agricultural intensification - Mixed-farming · Pastoral systems · Practice theory · West Africa

\section{Introduction}

Processes of intensification of livestock production by pastoralists are taking place across West Africa (Ramisch 1998; Buhl 1999; Demirag 2004; La Rovere et al. 2005). Processes which involve crop-livestock interactions are generally studied within an evolutionary framework of mixed-farming systems, rather than pastoral systems (Powell et al. 2004). I argue that mixed-farming systems and intensive pastoral systems are distinctly different, even though they both involve the integration and intensification of livestock production in agricultural systems. In this

M. Moritz $(\bowtie)$

Department of Anthropology, The Ohio State University,

174 W. 18th Avenue, Columbus, OH 43210-1106, USA

e-mail: moritz.42@osu.edu; mark.moritz@gmail.com article I will explain how and why crop-livestock interactions take different forms in mixed-farming systems and in intensive pastoral systems, and why it is important to distinguish between the two production systems. I apply Bourdieu's $(1980,1987)$ theoretical constructs of "habitus" and "capital" to illuminate my claims of an ethnographic case study of pastoral intensification in the Far North Province of Cameroon. I describe how peri-urban FulBe in the Far North Province of Cameroon have adapted to population pressure on resources by integrating and intensifying livestock production in an agricultural system, while simultaneously pursuing extensive strategies. ${ }^{1}$

The intensification of livestock production and its integration in African mixed-farming systems has been the subject of many studies (e.g., Pingali et al. 1987; McIntire et al. 1992; Okoruwa et al. 1996; Smith et al. 1997; Mortimore 1998, p. 187; Fanchette 1999; Williams et al. 1999). ${ }^{2}$ In mixed farming systems, livestock serve several purposes: manure can be used as fertilizer, animals can be used for tillage and transport; and animals can be marketed and the revenues can be re-invested in agriculture. Michael Mortimore and Mary Tiffen of the Drylands Research group have shown that this strategy has successfully been used by African farmers to adapt to increasing demographic pressures on natural resources by pursuing this strategy of integration and intensification of livestock in agricultural systems (Mortimore 2000, 2005; Tiffen 2004). But in this same model of sustainable dryland development there appears to be no role for pastoral systems, to wit: "the more

\footnotetext{
${ }^{1}$ In the far North of Cameroon, they call themselves FulBe, but the speakers of Fulfulde are also known as Fulani in the Anglophone literature or Peul in the Francophone literature. There are about 20 million speakers of Fulfulde, who can be found throughout West Africa from Senegal in the west to Sudan in the east.

${ }^{2}$ For a history of the mixed-farming model see Sumberg (1998).
} 
likely future scenario is of mixed farmers, some of whom will be ex-pastoralists, who combine crop production and livestock raising in an integrated system" (Tiffen 2004, p. 15). Researchers do not recognize that pastoral systems can likewise intensify without becoming merely a component part of a mixed-farming system. They can develop along a separate trajectory that remains focused on animal husbandry.

There are a number of reasons that researchers have focused on processes for integrating livestock in a mixedfarming system. In the last 50 years pastoralists have moved south into agricultural zones (Boutrais 1986, 1990; Bassett 1994; Bassett and Turner 2007) while agriculturalists have moved north into the pastoral zones (Thébaud 2002). These two processes thereby integrated the two production systems in geographical and social space. In other words, farming households incorporated livestock into their farms and pastoral groups settled and established farms alongside their herds (Raynaut 1997, 2001). Farmers have increasingly invested surplus wealth by purchasing livestock, a decision encouraged by agricultural extension workers promoting the use of tillage employing the plow, and collecting and applying manure to their agricultural lands. Most importantly, researchers studying the integration of livestock in mixed-farming systems implicitly assumed that there was no future for traditional extensive pastoral systems, and believed that traditional pastoralists should settle and integrate agriculture into their production system-in short become farmers (e.g., Njoya et al. 1997, p. 120).

The assumption that there is no future for pastoralism also informs models of agricultural transition in which the intensification of livestock production evolves out of agricultural systems (and not out of pastoral systems) (de Haan et al. 1996; Steinfeld 1998; Powell et al. 2004). These models do not distinguish between mixed-farming systems and intensive pastoral systems. Weber et al. (1996, p. 140), for example, postulate a pathway from traditional pastoral systems in which herders depend on fallow and free forage to more intensive husbandry systems in which animals are confined, and crop residues are harvested and preserved as fodder. In this model, pastoralists become mixed-farmers, and intensified livestock production indeed supports agricultural development, but there is no separate trajectory solely for intensification of pastoral production systems.

Unlike for agricultural systems, there are few studies of the intensification of pastoral systems (except Bencherifa and Johnson 1990). This is largely because within the pastoral literature, pastoralists cease to be pastoralists when they settle and take up agriculture. And while the concept of intensification frequently has been used to explain land use changes in agricultural systems, it has seldom been used in reference to pastoral systems. Because pastoralists' exploitation of grazing land generally cannot be readily intensified by adding more animals without overgrazing and degrading the land, it has not been immediately obvious how pastoral systems could be intensified. However, there are in fact multiple ways that intensification of pastoral systems may be conceptualized. For example, systems can become more intensive through an increase of labor, capital and/or technology inputs per unit of land and/ or animals (Galaty and Johnson 1990, p. 18): This is how I define pastoral intensification in this article. ${ }^{3}$

I examine this concept by presenting details from an ethnographic case study of a peri-urban pastoral system in which FulBe in the Far North of Cameroon have intensified their pastoral production system by increasing their capital inputs in animal stock to cope with population pressures on grazing resources. I have used this case study in prior articles to support different arguments about pastoral development (Moritz 2008) and the future of West African pastoralism (Moritz et al. 2009). Here I use the case study to argue and demonstrate that crop-livestock interactions in intensive pastoral systems differ significantly from those found in mixed-farming systems.

\section{Theoretical framework}

To explain the differences between intensive pastoral systems and mixed-farming systems in West Africa, I use Bourdieu's (1980) theory of practice and class distinction (1986, 1987). In particular, I use his concepts of structure, habitus, practice, practical logic; and social, cultural, economic, and symbolic capital to explain two important differences between pastoralists and mixed-farmers. First, I use practice theory to explain why pastoralists make different decisions and have different goals from mixedfarmers when they integrate livestock in agricultural systems. Second, I use Bourdieu's theory of class distinction to explain how FulBe pastoralists draw on different kinds of capital as they pursue the extensive strategy of entrusting cattle to other, more mobile pastoralists. These are but two examples of how cultural differences between pastoralists and mixed-farmers lead to different forms of crop-livestock interactions. Although anthropologists have long shown how economic practices are shaped by culture (for a review see, Wilk and Cliggett 2007), there has been little discussion about the cultural differences between pastoralists and agriculturalists and the implications for the evolution of crop-livestock interactions (except Bonfiglioli 1990).

\footnotetext{
3 I have defined "mixed-farming" as those agricultural systems in which households integrate crop and livestock production and "intensive pastoral systems" as those pastoral systems in which labor, capital and/or technology inputs per unit of land and/or animals have been increased (see Galaty and Johnson 1990, p. 18).
} 
Bourdieu's theory of practice is useful for describing how culture shapes processes of intensification (Jenkins 1992).

Practice theory

Practice theory addresses two central questions: (a) how does the system shape individual practice, and (b) how do individual practices shape the system (Bourdieu 1980; Giddens 1984; Ortner 1984)? Key concepts in Bourdieu's (1980) theory of practice are habitus and practice. Habitus can be described as an individual's system of acquired dispositions that work as a generative scheme of action (but which does not determine action). Individuals acquire these dispositions, which are embodied and mostly learned through experience, as they are socialized within families, social groups, and institutions. Habitus produces practice, which is best described as what people do in everyday life. Practical or common sense (e.g., logic) is often described as "the feel for the game" in which the game can stand for social life but also for other domains, including economic behavior

A good way to illustrate practice theory and the relationships between structure, agency, habitus and practice is to use Bourdieu's (1980) metaphor of social life as a game (Jenkins 1992). Games are controlled by rules, but these rules change over time and are not the only things that shape how individuals play. Individuals learn to play partly through explicit instruction but mostly through practice. Much of this learning is through bodily experience. In games, players seek to win by being strategic, which may be conscious in the form of a game plan, but also unconscious in moves during the play itself. Although each game is different, there is regularity in the way games are played (aside from the regularity provided by the rules) and different teams play in recognizably different ways (in part because they practice together). The regularity is the structure that shapes players' habitus and in turn informs their practice. Bourdieu's metaphor of the game is similar to Goffman's (1959) metaphor of social life as performance with roles, scripts, and actors who improvise.

The habitus and everyday practices of individual actors are shaped by the history and objective structures of their social world (Jenkins 1992, p. 141). It is thus important to consider the larger objective structures in which peri-urban FulBe historically have been embedded in order to understand their production strategies and changes therein. A good example to illustrate this is to compare the value of cattle in farming and herding communities. In farming communities, cattle have primarily economic value as a source of manure, milk, or draught power). In contrast, cattle in pastoral systems historically have had social and symbolic value (e.g., cattle exchanges cemented social relations, ownership gave prestige) in addition to economic value. These historic contexts, internalized in individual's habitus, shape-but do not limit or determine-how herders and farmers manage their cattle.

Bourdieu's Distinction (1987) is a study of the tastes and preferences of the French bourgeoisie. It describes how individuals in the different classes in France use different forms of capital in their struggles to gain status and social recognition. Bourdieu (1986) describes these forms of capital as follows: (a) social capital refers to those resources gained through social networks; (b) economic capital refers to direct command over economic resources; (c) cultural capital refers to knowledge, skills, and education that can be used to gain resources; and (d) symbolic capital refers to resources that can be gained through an individual's honor, prestige or recognition. These different kinds of capital are resources that individuals can use (or "capitalize") in their social struggles or economic pursuits. Bourdieu's (1986, 1987) theory of class distinction and his concepts of different forms of capital are very useful for analyzing how the pastoral background of peri-urban pastoralists allowed them to pursue the extensive strategy of entrustment while minimizing the transaction costs of entrustment by drawing from different forms of social, cultural, economic, and symbolic capital which agriculturalists do not have. ${ }^{4}$ For example, comparing the number and kind of social relations of mixed-farmers and peri-urban pastoralists, one finds that pastoralists' social networks give them greater access to resources such as reliable and trustworthy herders. Bourdieu's theoretical concepts assist analysts to understand people's everyday (e.g., agricultural or pastoral) practices and how they shape-and are shaped-by the larger sociocultural context.

\section{Methods}

The study of the peri-urban pastoral system was part of larger ethnographic study of three pastoral systems-periurban, agro-pastoral, and nomadic-in the Far North of Cameroon from September 2000 to August 2001 (see Moritz 2003). Because the goal of the larger comparative study was to assess whether integration in the market economy leads to the disappearance of livestock exchanges, data collection focused on market integration (in terms of household production and consumption) and livestock ownership and exchanges. I conducted multiple household surveys throughout the year to collect demographic, agricultural, and consumption data on individual households. I also conducted herd surveys and documented herd management, in particular production costs, as well as ownership and exchanges of animals. In order to collect

\footnotetext{
${ }^{4}$ However, agriculturalists may have other forms of capital.
} 
reliable data on livestock ownership and exchanges, which FulBe consider sensitive and private, I conducted an indepth and detailed study of all pastoral households in three villages (rather than a cross-sectional study of randomly selected pastoral households across multiple villages in the Far North Province). The villages were selected because they represented different degrees of integration in the market economy. Measurement of market integration was based on distance from the provincial capital Maroua, the commercial center of the province. All three villages are located along an axis that links Maroua with the transhumance area of the Logone floodplain. Analysis of ownership and exchange data showed that the pastoral intensification and the associated increase in production costs were responsible for the demise of livestock exchanges, rather than caused by general market integration (more in Moritz 2003). In this article, I will focus my analysis on the intensification of the peri-urban pastoral system; data for the agro-pastoral and nomadic systems are presented in tables to show the degree of intensification in the peri-urban system (more in Moritz 2003, pp. 70-76).

The research setting

The Far North Province of Cameroon has a semi-arid climate with a single rainy season. Rainfall is characterized by high spatial and temporal variability with frequent drought. During the 8-month dry season from October to May cattle lose considerable weight and become more susceptible to diseases. Animal losses peak during this season and it has been dubbed the "dry season crunch" (Frechou 1984, p. 431). The primary goal of pastoralists is to overcome the dry season crunch. This is achieved through a focus on animal nutrition whereby pastoralists seek to make cattle gain weight in the rainy season so that animals have enough reserves to survive the long dry season, and thereby prevent weight loss in the dry season (see also Schareika 2003). Traditionally, pastoralists prevented weight loss of their animals through transhumance, a term that denotes moving their animals to the rangelands with the highest quality and quantity of forage.

Two phytogeographic zones of vegetation characterize the province: Sudanian in the southern grades and Sahelian in the northern Logone floodplain. Although the Sahelian zone is characterized by lower rainfall and a shorter rainy season, the seasonal flooding of the Logone floodplain makes this zone one of the most important dry season grazing lands in the Chad Basin. Pastoralists from Cameroon and neighboring Nigeria and Niger trek each November to the Logone floodplain when the water retreats to exploit the high quantity and quality of the rangelands. At the start of the rainy season, the Cameroonian pastoralists return to the higher elevated dunes of the Diamaré,



Fig. 1 The Far North Province of Cameroon

while pastoralists from neighboring countries return to their respective countries. The Diamaré plains and the Logone floodplain form complementary resources for pastoralists in the Far North (see Fig. 1); the former provide pastures in the rainy season, the latter in the dry season (Requier-Desjardins 2001, p. 28).

Although the peri-urban village of Wuro Badaberniwol is located about $10 \mathrm{~km}$ east of Maroua, which is he provincial capital of the Far North province, Wuro Badaberniwol has no running water or electricity. The village consists of 26 FulBe, RiimayBe, and Kanuri households, most of whom have lived in the village for nearly 100 years. Six of the households are FulBe pastoralists, and these were the focus of my study. Households were large, in part because the majority of the peri-urban pastoralists maintained polygamous marriages. The average household size was 14.5 people (see Table 1). All pastoral households practiced diversified livelihood strategies that included: animal husbandry (cattle, sheep, goats, chickens); subsistence agriculture (sorghum, millet, maize); cash crops (cotton); and off-farm income (mainly trade, some retail). The pastoral households were relatively wealthy. They owned most of their agricultural fields and relied heavily 
Table 1 Characteristics of peri-urban households

\begin{tabular}{lllllll}
\hline Household & $\begin{array}{l}\text { Age of household } \\
\text { head }\end{array}$ & $\begin{array}{l}\text { Number } \\
\text { of people }\end{array}$ & $\begin{array}{l}\text { Number of } \\
\text { nuclear families }\end{array}$ & $\begin{array}{l}\text { Land ownership } \\
\text { in hectare }\end{array}$ & $\begin{array}{l}\text { Number of cattle } \\
\text { in village herd }\end{array}$ & $\begin{array}{l}\text { Number of cattle } \\
\text { in bush herd }\end{array}$ \\
\hline 1 & 46 & 27 & 2 & 7 & 27 & 26 \\
2 & 63 & 27 & 4 & 8 & 21 & 60 \\
3 & 30 & 6 & 1 & 3 & 32 & 34 \\
4 & 65 & 16 & 1 & 6 & 16 & 200 \\
5 & 56 & 16 & 2 & 5 & 26 & 57 \\
6 & 57 & 10 & 2 & 4.3 & 20.3 & 75 \\
Average & 53 & 14.5 & 1.7 & & & NA \\
\hline
\end{tabular}

on hired labor for pastoral and agricultural activities. Most years, peri-urban pastoralists produce a millet and sorghum surplus, and despite the high costs of inputs for the cattle herds, the financial returns and herd growth were positive.

In recent years, Wuro Badaberniwol has slowly been incorporated into the neighboring urban center of Maroua, which grew from 60,000 to over 300,000 inhabitants between 1976 and 2000 (Seignobos and Iyébi-Mandjek 2000) (see Table 2). Increasing urbanization has been accompanied by an expansion of agriculture at the expense of the bush around Maroua as many urban dwellers continue to farm. Consequently, there are practically no rangelands within a $20-\mathrm{km}$ radius of Maroua and cattle simply cannot survive on the natural forage in the periurban area, a condition which affects thousands of agropastoralists (Moritz 2003, p. 191).

It is difficult to make general assessments of the grazing pressures on rangelands in the Far North Province because there are no reliable surveys of the number of livestock in the province or the land available for grazing (Moritz 2003, pp. 187-191). I used population densities and a biomass study to estimate the grazing land availability and grazing capacity in each village (see Table 3 ). Grazing capacity is defined as the number of animals that can live off the forage available in a determined period. The biomass study measured natural forage availability during the 2001 dry season. While the biomass study did not measure changes in rangeland productivity or degradation, it clearly showed that practically no palatable forage was available in the peri-urban area.

\section{Ethnographic case study of a peri-urban pastoral system}

Peri-urban pastoralists have adapted to the lack of useable natural forage by splitting their cattle into two distinct herds, bush and village, with completely different management

Table 2 Population growth and density in the Far North Province, 1976-2000

\begin{tabular}{llllll}
\hline & 1976 & 1987 & 1992 & 1995 & 2000 \\
\hline Population in the Far North Province & $1,396,124$ & $1,880,866$ & $2,141,000$ & $2,467,000$ & $2,838,000$ \\
Density per $\mathrm{km}^{2}$ in the Far North Province & 40.8 & 54.9 & 62.5 & 72.0 & 82.8 \\
Population of Maroua & 62,600 & 123,000 & 162,000 & 210,000 \\
\hline
\end{tabular}

The numbers for 1995 and 2000 are estimates. All numbers are from the Atlas de la Province Extrême-Nord Cameroun (Seignobos and IyébiMandjek 2000)

Table 3 Estimated grazing capacity and population densities

\begin{tabular}{lllll}
\hline & Vegetation type & $\begin{array}{l}\text { Dry matter } \\
\text { biomass }(\mathrm{kg} / \mathrm{ha})\end{array}$ & $\begin{array}{l}\text { Grazing capacity } \\
\left(\text { animals/day/km }{ }^{2}\right)\end{array}$ & $\begin{array}{l}\text { Population density } \\
\left(\mathrm{people} / \mathrm{km}^{2}\right)\end{array}$ \\
\hline Peri-urban area & Woody/grass savanna & 1,361 & 0.11 & $50-150$ \\
Agro-pastoral area & Woody/grass savanna & 2,992 & 0.87 & $10-50$ \\
Logone floodplain & Grass savanna & 12,556 & 5.74 & $1-25$ \\
\hline
\end{tabular}

The method used to assess of dry matter biomass was developed by Breman and de Ridder (1991) and operationalized for the Far North Province (van der Jagt and Abatcha 1997). Grazing capacity, the number of animals that can be supported by the available forage in a determined period, is calculated per square kilometer for the last 3 months of the dry season of 2001 (March-June). Population densities are from Atlas de la Province Extrême-Nord Cameroun (Seignobos and Iyébi-Mandjek 2000) 
practices. They entrust the bush herd to nomadic pastoralists or salaried herders who are permanently on transhumance between the Logone floodplain and the Mindif-Moulvoudaye region. Pastoralists feed the animals remaining in the village (termed the village herd) cottonseed cakes, hulls, and sorghum stalks in the dry season to compensate for the lack of natural forage. In the rainy season, the village herd is sent on a transhumance to the Mindif-Moulvoudaye region. Thus, peri-urban pastoralists pursue both intensive and extensive strategies to cope with the disappearance of grazing lands in the peri-urban area.

Brookfield (1972) has pointed out that intensive systems are diverse systems that involve a range of economic practices which are governed by different considerations (p. 44). This is also true for peri-urban pastoral systems. Members of peri-urban households are involved in a wide range of economic activities including animal husbandry, subsistence agriculture, cultivation of cash crops, and commercial activities. All these economic activities are governed by different considerations; for example, the main worry regarding care of the village herd is managing the financial costs of cottonseed cakes, while the main concern regarding the bush herd is reducing the risk of losses due to theft.

\section{Intensive strategies}

The use of cottonseed cakes in the peri-urban pastoral system is not unprecedented. FulBe pastoralists in West Africa have supplemented natural forage with sorghum, millet stalks and cottonseed for centuries. The use of cottonseed cakes is not limited to the Far North of Cameroon; its use is widespread today among FulBe agro-pastoralists in West Africa (see for example, Buhl 1999; Demirag 2004). However, the recent increase in use of, and dependence on, cottonseed cakes in the peri-urban area of Maroua in the 1990s is new. Although sorghum, millet, and corn stalks continue to provide an important source of nutrition and roughage, cottonseed cakes and hulls are now the primary source of feed for cattle during the dry season, such that they substitute rather than supplement natural forage.

The intensification of the peri-urban pastoral system through increased use of cottonseed cakes has been an incremental and piecemeal process that started in the early 1980 s, but really took off in the early 1990s. By feeding the village herd cottonseed cakes, peri-urban pastoralists have increased the capital inputs per unit of production, in which the unit of production is cattle rather than land. The intensification thus involves a transition from a production system that relies on free natural forage to a capital-intensive system that relies on costly cottonseed cakes, cottonseed hulls, sorghum stalks, and other commoditized inputs. It is important to note that peri-urban pastoralists did not intensify their production system to increase production for household subsistence or marketing. The foremost goal of peri-urban pastoralists was to get their cattle through the dry season crunch and prevent a decline in animal production and reproduction. Intensification was a response to population pressures on natural resources that led to the disappearance of rangelands. The majority of the peri-urban pastoralists fed their cattle enough cottonseed cakes to survive. As a result, their animals were not much fatter than the cattle in the other two pastoral systems I studied. During the 2000-2001 dry season, however, reproductive rates were higher in the peri-urban village than in the other two pastoral systems (Moritz 2003, p. 229).

The changes in the peri-urban pastoral system have also led to a more labor-intensive system. The use of cottonseed cakes has radically altered the daily management of the village herds. Cattle are fed cottonseed cakes twice daily, once in the morning before they go to pasture and once in the evening upon return. Feeding cattle cottonseed cakes is labor intensive because, in all but one pastoral household, cattle are fed individually, one-by-one, from enamelware bowls rather than from a common trough. In addition to one person feeding the animals, another person must control the waiting animals, which are eager to get their twice-daily ration. Depending on the number of animals, feeding can take more than $3 \mathrm{~h}$ a day. Because of these labor demands village herds are relatively small: 24 animals on average.

The purchase of cottonseed cakes and hulls is also timeconsuming and stressful because of unreliable and insufficient supplies. In 2000-2001 about half of the cottonseed cake production of the SODECOTON (Société de développement du coton du Cameroun) was sold directly to cotton planters at a fixed price. The remainder was sold to businessmen who retail the cottonseed cakes at double or triple the price (depending on the progression of the dry season). Peri-urban pastoralists perceived this secondary market as speculative because only wealthy and wellconnected businessmen are able to purchase cottonseed cakes in large quantities. It is unclear whether scarcity towards the end of the dry season was the result of demand outstripping supply, an inefficient market, or speculation on part of the middlemen. Towards the end of the dry season, when cottonseed cakes become scarce, peri-urban pastoralists spend hours everyday to find cottonseed cakes at the lowest possible price.

\section{Extensive strategies}

Until the end of the 1970s, peri-urban pastoralists split their herds in the dry season. They would send their best animals (hooreeji) with a male herder from the household on transhumance to the Logone floodplain together with herds from neighboring villages, and kept a few milk cows 
Table 4 Herd data from three pastoral systems, 2000-2001

\begin{tabular}{|c|c|c|c|c|}
\hline & \multicolumn{2}{|c|}{ Peri-urban pastoralists } & \multirow[t]{2}{*}{ Agro-pastoralists } & \multirow[t]{2}{*}{ Nomadic pastoralists } \\
\hline & Village herd & Bush herd & & \\
\hline Fecundity rate & 0.52 & 0.44 & 0.38 & 0.40 \\
\hline Losses (deaths, theft, lost) (\%) & 4.5 & 9.2 & 6.0 & 2.5 \\
\hline Average herd growth $(\%)$ & 21.0 & 5.3 & 15.7 & 4.5 \\
\hline Production costs per animal in FCFA* & 12,768 & 3,201 & 1,735 & 2,417 \\
\hline Cottonseed cake costs per herd in FCFA* & 144,833 & 4,000 & 3,407 & 8,763 \\
\hline Costs of cottonseed cakes as percentage of total costs $(\%)$ & 62 & 2 & 13 & 5 \\
\hline Returns on financial inputs & 1.3 & 3.5 & 6.0 & 12.3 \\
\hline Number of animals per owner* & 24 & 75 & 18 & 76 \\
\hline Number of herds & 6 & 5 & 16 & 8 \\
\hline
\end{tabular}

All numbers are averages per village. "Losses" are an indication of the risks associated with each strategy; it includes all the losses that can be due to herder negligence (e.g., deaths, thefts, and losses). "Overall herd growth" considers all the variables that affect herd size, including births, deaths, sales, theft, and exchanges (except for transfers between village and bush herd). "Returns on financial inputs" is derived from an economic model that uses herd parameters from each village and reflects natural herd growth expressed in financial terms divided by the production costs (see Moritz 2003). All the data were collected in bi-monthly surveys between September 2000 and August 2001. The differences between means of the variables marked with an asterisk (*) are statistically significant at the 0.001 level, using one-way ANOVA (SPSS 16.0 for Mac)

(cureeji) in the village. In the early 1980s, the herds were split permanently. One part was kept in the village (wurooji) and other part was entrusted to nomadic pastoralists and/or hired herders (laddeeji). One of the main reasons for the permanent split was the insecurity in the Logone floodplain where numerous herders lost their lives defending their herds against cattle thieves (Scholte et al. 1996). Peri-urban pastoralists were not willing to risk their own lives, but they were willing to let other (i.e., hired) herders take that risk even though the decision was anticipated to entail suffering some livestock losses.

Because of the disappearance of pastures around the village, peri-urban pastoralists keep approximately $70 \%$ of their cattle permanently in the bush (Moritz 2003, p. 222). Some entrusted their cattle to nomadic pastoralists in an institutionalized form of entrustment that involved the appointment of a guardian or kaliifa, who is responsible for the cattle and supervises the herder (Moritz 2003, p. 322). Other peri-urban pastoralists entrusted their cattle to herders that they directly hired and supervised themselves. The annual production costs of the bush herds were much lower than the village herds-2,984 FCFA versus 12,371 FCFA per animal-and only slightly higher than those of nomadic herds: 2,344 FCFA (see Table 4). ${ }^{5}$

The greatest disadvantage of the entrustment arrangement was that herders and guardians could not always be trusted. There was always the risk that herders would sell cattle without permission and tell the owner that cattle

\footnotetext{
${ }^{5} \mathrm{I}$ have used the conversion of $\$ 1=750$ FCFA (Franc de la communauté financière d'Afrique). During my research in 20002001, the exchange rate fluctuated between 700 and 775 FCFA to one dollar.
}

died, or were lost or stolen. The herd data show that herd losses due to deaths, theft, and lost animals is considerably higher in the bush herd: $12.0 \%$ compared to $3.4 \%$ in the village herd (see Table 4). Peri-urban pastoralists used a number of strategies to minimize this risk. They frequently visited their herds in the bush, sometimes travelling for a day or more and staying for a night or two, to keep a close eye on the herder and check the health of their cattle. Herd owners knew all their animals, whether they had 30 or 200, and hired herders had to account for every FCFA that they had spent on the animals and for which they sought reimbursement. To label these peri-urban pastoralists as "absentee owners" would in many ways misrepresent their active management of the herd.

Intensive and extensive strategies are integrated in one household economic system. Exhausted or emaciated animals from the bush herd were transferred to the village where they were fed supplementary feed, while cattle bought on the market were put discreetly in the bush herd. Similarly, cash from sales of bush animals was used to buy cottonseed cakes for the village animals. Peri-urban pastoralists also found hired herders for their village herds through their social networks in the Logone floodplain. Resources were thus exchanged frequently between bush and village herds.

\section{Discussion}

The ethnographic data presented above show that the croplivestock interactions in intensive pastoral system are different from those in mixed-farming systems described in 
the literature (e.g., Pingali et al. 1987; McIntire et al. 1992; Okoruwa et al. 1996; Smith et al. 1997; Mortimore 1998, p. 187; Powell et al. 2004). I argue that these differences are sociocultural and can be explained using Bourdieu's (1980, 1986, 1987) concepts of habitus/practice and different forms of capital (see also, Mazzucato and Niemeijer 2002). Bourdieu's concepts are extremely useful when examining social phenomenon, and for understanding a wide range of agricultural systems.

Even though the peri-urban pastoral production system has undergone major changes, the interdependence with cattle continues to shape the lives of peri-urban FulBe socially, culturally, economically, and ideologically (Galaty and Johnson 1990, p. 2; Chang and Koster 1994, pp. 8 9). As a result, crop-livestock interactions take a different form in pastoral systems than in agricultural systems, even though they may appear to be very similar.

\section{Habitus and history}

To understand how the contemporary habitus of peri-urban pastoralists shapes their production strategies, one also has to consider the historical context that has shaped that habitus. Spencer (1998) has argued that Islamic pastoralists in West Africa have been more integrated socially, culturally, politically, and economically in larger regional systems that were centered on urban centers than are non-Islamic pastoralists in East Africa. Because of their integration in these larger systems, Islamic pastoralists have been more involved in trade and more open to diversification and the opportunities that linkages with urban centers offered. Historically, Islamic pastoralists in West Africa like the FulBe and the Tuareg have indeed been more integrated in regional systems than East African pastoralists. In addition, agricultural and pastoral production systems have been more spatially and economically integrated in West Africa than in East Africa, which is in large part due to bioclimatic differences (Ellis and Galvin 1994). The integration of pastoralism in regional political systems and agricultural production systems enabled peri-urban FulBe to adapt to population pressures on natural resources by intensifying their production system, both because the integration in larger systems offered them opportunities and because they were more open to exploiting them (due to the fact that their habitus was shaped by these same structures).

Peri-urban pastoralists identified themselves as FulBe, which for them involved a commitment to Islam, trade, and cattle. Commitment to cattle is thus not the only marker of FulBe identity, but it is a critical one that distinguishes them from other agricultural groups in the Far North of Cameroon. This commitment is a product of their socialization, which has shaped their habitus. Peri-urban pastoralists grew up in pastoral households and worked as herders themselves (and a few of them went on transhumance with the family herd to the Logone floodplain). And even though peri-urban pastoralists are no longer herding themselves, they have practical and in-depth knowledge of pastoralism which guides their decision-making in the everyday and in longterm management of the herds. As a result, peri-urban pastoralists have different goals and make different decisions than mixed-farmers. For example, peri-urban pastoralists cultivate cotton primarily for cottonseed cakes to support livestock production rather than for cash. The primary goal of peri-urban pastoralists is to get their animals through the dry season, not to increase milk or meat production for the market or to increase agricultural production using manure, which is not typically used on agricultural fields; instead, manure accumulates in large mounds within pastoral compounds. In this way, agricultural production supports livestock production, rather than the other way around, e.g., as in mixed-farming systems.

The habitus not only shapes goals and decision-making, it also shapes everyday social interactions, including those with herders to which peri-urban pastoralists entrust their bush herds. The "game of pastoralism" is one that periurban pastoralists play well and enjoy playing. Peri-urban pastoralists in my study made frequent and extended trips to their bush herds in the Logone floodplain and the Mindif-Moulvoudaye area. As a result, they knew the transhumance areas in the province well. They also participated in social networks that connected them with nomadic pastoralists throughout the Far North Province (and beyond); they knew "who was who" in the floodplain and they were familiar with the cultural practices of nomadic pastoralists. They enjoyed being part of the social world of nomadic pastoralists and used their knowledge and skills to negotiate their relations with nomadic pastoralists to whom they entrusted their herds. Moreover, they had the social, cultural, and economic capital that allowed them to entrust their herds to nomadic pastoralists, while minimizing the risks associated with entrustment.

The entrustment of cattle to nomadic pastoralists and/or hired herders is a profitable but also risky strategy that periurban pastoralists employ to cope with population pressures on grazing resources in the peri-urban area. They risk losing all their animals due to theft (by their herders or others). To minimize this risk, peri-urban pastoralists use different kinds of capital. First, they use economic capital to cover the costs of frequent and extended trips to the Logone floodplain and Mindif-Moulvoudaye area to monitor their herds and herders. Second, they use social capital from their extensive social network that includes other mobile pastoralist, but also traditional authorities and livestock traders in the transhumance areas, to monitor their herds and herders. Third, they use cultural capital of their knowledge of pastoralism in their relations with nomadic pastoralists and/or 
hired herders. Finally, they use symbolic capital of Islam and their identity as pious Muslims to sanctify the entrustment of cattle by invoking Islamic notions of trust and responsibility by appointing a kaliifa, a person who is responsible for what is entrusted to him (Moritz 2003). They are therefore able to pursue extensive strategies within their pastoral production system that are not apparently or readily available to mixedfarmers.

\section{Conclusion}

The practical implication of my theoretical argument is that development policies that support the integration and intensification of livestock production in agricultural systems cannot be the same for all farming and pastoral systems. In mixed-farming systems, livestock plays a supportive role (Boserup 1965; Powell et al. 2004; Mortimore 2005). In pastoral intensification, the roles are reversed, and agriculture plays a supportive role (Bencherifa and Johnson 1990). Peri-urban pastoralists in the Far North of Cameroon, for example, cultivate cotton primarily for cottonseed cakes (rather than to obtain cash) because livestock production is privileged in their decision making. The difference between intensive pastoral systems and mixed-farming systems is also reflected in the practical knowledge and everyday practices of pastoralists and mixed-farmers. For example, Bonfiglioli (1990, p. 261) noted that agro-pastoralists with an agricultural background have neither the competence nor the passion for animal husbandry, and the reverse is true for many pastoralists. Finally, pastoralists can draw from multiple forms of capital to reduce the transaction costs of using extensive pastoral strategies, which are integral to their adaptation to the pressure on grazing lands in the peri-urban area.

Pastoralists across West Africa are adapting to population pressures on grazing resources either by movement to the sub-humid zones and/or integration and intensification of livestock production in agro-pastoral systems (Moritz et al. 2009). It is critical to understand these intensification processes and how they are shaped by the practical logic of pastoralists (and not the logic of mixed-farmers) in order to give the appropriate support to further develop these systems as they adapt to larger processes of global climatic and social change.

Acknowledgments The National Science Foundation (BCS9910557), the Wenner-Gren Foundation (Gr. 6661), the International Studies and Overseas Program (UCLA), the Anthropology Department at UCLA, and the James S. Coleman African Studies Center (UCLA) have supported this research. I thank the University of Ngaoundére, Cameroon for granting research permission and research affiliation during my study in 2000-2001. I also want to thank Parker Shipton and Mats Widgren for comments on an earlier version of this article presented at the annual meeting of the American Anthropological Association in Washington DC in 2007. I also would like to thank Jeffrey Cohen, Colin West, the editor Harvey James and three anonymous reviewers for their insightful and useful critiques.

\section{References}

Bassett, T.J. 1994. Hired herders and herd management in Fulani pastoralism (Northern Cote d'Ivoire). Cahiers d'Etudes Africaines 133-135 (1-3): 147-173.

Bassett, T.J., and M.D. Turner. 2007. Sudden shift or migratory drift? Fulbe herd movements to the Sudano-Guinean region of West Africa. Human Ecology 35 (1): 33-49.

Bencherifa, A., and D.L. Johnson. 1990. Adaptation and intensification in the pastoral systems of Morocco. In The world of pastoralism: Herding systems in comparative perspective, ed. J.G. Galaty and D.L. Johnson, 394-416. New York, NY: The Guilford Press.

Bonfiglioli, A.M. 1990. Pastoralisme, agro-pastoralisme et retour: Itinéraires sahéliens. Cahiers des Sciences Humaines 26 (1-2): 255-266.

Boserup, E. 1965. The conditions of agricultural growth. London, UK: Allen and Unwin.

Bourdieu, P. 1980. The logic of practice. Stanford, CA: Stanford University Press.

Bourdieu, P. 1986. The forms of capital. In Handbook of theory and research for the sociology of education, ed. J.G. Richardson, 241-258. Westport, CT: Greenwood Press.

Bourdieu, P. 1987. Distinction: A social critique of the judgment of taste. Cambridge, MA: Harvard University Press.

Boutrais, J. 1986. L'expansion des eleveurs Peul dans les savanes humides du Cameroun. In Pastoralists of the West African savanna, ed. A.H.M. Kirk-Greene and M. Adamu, 145-160. Manchester, UK: Manchester University Press.

Boutrais, J. 1990. Les savanes humides, dernier refuge pastoral: L'exemple des WoDaaBe' Mbororo'en de Centrafrique. GeneveAfrique 28: 65-90.

Breman, H., and N. de Ridder. 1991. Manuel sur les pâturages des pays sahèliens. Paris, France: Karthala.

Brookfield, H.C. 1972. Intensification and disintensification in Pacific agriculture. Pacific Viewpoint 13 (1): 30-48.

Buhl, S. 1999. Milk, millet, and mannerisms: Gendered production among pastoral and agropastoral Fulbe households in northern Burkina Faso. Dissertation, Department of Anthropology, University College London, London.

Chang, C., and H.A. Koster. 1994. Introduction. In Pastoralists at the periphery: Herders in a capitalist world, ed. C. Chang and H.A. Koster, 1-15. Tuscon, AZ: The University of Arizona Press.

de Haan, C., H. Steinfeld, and H. Blackburn. 1996. Livestock and the environment interactions: Issues and options. Rome, Italy: Food and Agriculture Organization.

Demirag, U. 2004. Handlungsräume agropastoraler Fulbe in Nordostnigeria: Eine vergleichende Studie in den Bundesstaaten Adamawa und Gombe. Dissertation, Institut für Afrika-Kunde, Hamburg, Germany.

Ellis, J., and K.A. Galvin. 1994. Climate patterns and land-use practices in the dry zones of Africa. BioScience 44 (5): 340-349.

Fanchette, S. 1999. Densité de population et intensification agropastoral en Haute Casamance. Espace, Populations, Sociétés 1: 67-81.

Frechou, H. 1984. L'élevage. In Le nord du Cameroun: Des hommes, une region, ed. J. Boutrais, 429-444. Paris, France: ORSTOM.

Galaty, J.G., and D.L. Johnson. 1990. Introduction: Pastoral systems in global perspective. In The world of pastoralism: Herding 
systems in comparative perspective, ed. J.G. Galaty and D.L. Johnson, 1-15. New York, NY: The Guilford Press.

Giddens, A. 1984. The constitution of society: Outline of the theory of structuration. Berkeley, CA: University of California Press.

Goffman, E. 1959. The presentation of self in everyday life. Garden City, NY: Doubleday Anchor Books.

Jenkins, R. 1992. Pierre Bourdieu. London, UK: Routledge.

La Rovere, R., P. Hiernaux, H. van Keulen, J.B. Schiere, and J.A. Szonyi. 2005. Co-evolutionary scenarios of intensification and privatization of resource use in rural communities of southwestern Niger. Agricultural Systems 83 (3): 251-276.

Mazzucato, V., and D. Niemeijer. 2002. Population growth and the environment in Africa: Local informal institutions, the missing link. Economic Geography 78 (2): 171-193.

McIntire, J., D. Bourzat, and P. Pingali (eds.). 1992. Crop-livestock interactions in sub-Saharan Africa. Washington, DC: The World Bank.

Moritz, M. 2003. Commoditization and the pursuit of piety: The transformation of an African pastoral system. Dissertation, Department of Anthropology, University of California at Los Angeles, Los Angeles, CA. Available at: http://anthropology. osu.edu/faculty/pages/MoritzResearch.php.

Moritz, M. 2008. Competing paradigms in pastoral development? A perspective from the Far North of Cameroon. World Development 36 (11): 2243-2254.

Moritz, M., B. Kyle, K.C. Nolan, S. Patrick, M.F. Shaffer, and G. Thampy. 2009. Too many people and too few livestock in West Africa? An evaluation of Sandford's thesis. Journal of Development Studies 45 (7).

Mortimore, M. 1998. Roots in the African dust: Sustaining the drylands. Cambridge, UK: Cambridge University Press.

Mortimore, M. 2000. Hard questions for pastoral development: A northern Nigerian perspective. In Elevage et gestion de parcours au Sahel: Implications pour le developpement, ed. E. Tielkes, E. Schlecht, and P. Hiernaux, 101-114. Stuttgart, Germany: Verlag Grauer.

Mortimore, M. 2005. Dryland development: Success stories from West Africa. Environment 47 (1): 10-21.

Njoya, A., D. Bouchel, A.-C.N. Tama, C. Moussa, A. Martrenchar, and L. Letenneur. 1997. Systèmes d'élevage et productivité des bovins en milieu paysan. In Agricultures des savanes du NordCameroun: Vers un développement solidaire des savanes d'Afrique centrale, ed. L. Seiny Boukar, J.F. Poulain, and G. Faure, 109-121. Montpellier, France: CIRAD.

Okoruwa, V., M.A. Jabbar, and J.A. Akinwumi. 1996. Crop-livestock competition in the West African derived savanna: Application of a multi-objective programming model. Agricultural Systems 52 (4): 439-453.

Ortner, S.B. 1984. Theory in anthropology since the sixties. Comparative Studies in Society and History 26 (1): 126-166.

Pingali, P., Y. Bigot, and H.P. Binswanger. 1987. Agricultural mechanisation and the evolution of farming systems in subSaharan Africa. Baltimore, MD: John Hopkins University Press.

Powell, J.M., R.A. Pearson, and P.H. Hiernaux. 2004. Crop-livestock interactions in the West African drylands. Agronomy Journal 96 (2): 469-483.

Ramisch, J. 1998. Cattle, carts, and cotton: Livestock and agricultural intensification in southern Mali. Dissertation, University of East Anglia, Norwich, UK.

Raynaut, C. 1997. Societies and nature in the Sahel. London, UK: Routledge.

Raynaut, C. 2001. Societies and nature in the Sahel: Ecological diversity and social dynamics. Global Environmental Change 11 (1): 9-18.

Requier-Desjardins, M. 2001. Elevages et transhumance à l'extremenord du Cameroun: Une étude des contrats d'acces aux paturages communs, enquetes en mileu pastoral et essai de modélisation contractuelle. Dissertation, Centre d'Economie et d'Ethique pour l'Environnement et le Developpement, U.F.R. des Sciences Sociales et des Humanites, Université de Versailles, et CIRAD, Saint-Quentin-en-Yvelines, France.

Schareika, N. 2003. Westlich der kälberleine: Nomadische Tierhaltung und naturkundliches wissen bei den Wodaabe südostnigers. Mèunster, Germany: Lit-Verlag.

Scholte, P., S. Kari, and M. Moritz. 1996. The involvement of nomadic and transhumance pastoralists in the rehabilitation and management of the Logone flood plain, north Cameroon. IIED Drylands Programme Issues Paper, (66): 1-21.

Seignobos, C., and O. Iyébi-Mandjek (eds.). 2000. Atlas de la Province Extrême-Nord Cameroun. Paris, France: IRD and MINREST.

Smith, J.W., A. Naazie, A. Larbi, K. Agyemang, and S. Tarawali. 1997. Integrated crop-livestock systems in sub-Saharan Africa: An option or an imperative? Outlook on Agriculture 26 (4): 237 246.

Spencer, P. 1998. The pastoral continuum: The marginalization of tradition in East Africa. Oxford, UK: Clarendon Press.

Steinfeld, H. 1998. Livestock and their interactions with the environment: An overview. In Foods, lands and livelihoodssetting the research agendas for animal science, ed. M. Gill, T. Smith, G.E. Pollott, E. Owen, and T.L.J. Lawrence, 53-66. Penicuik, Midlothian, Scotland: British Society of Animal Science.

Sumberg, J. 1998. Mixed farming in Africa: The search for order, the search for sustainability. Land Use Policy 15 (4): 293-317.

Thébaud, B. 2002. Foncier pastoral et gestion de l'espace au Sahel. Paris, France: Karthala.

Tiffen, M. 2004. Population pressure, migration and urbanization: Impacts on crop-livestock systems development in West Africa. In Sustainable crop-livestock for improved livelihoods and natural resource management in West Africa, ed. T.O. Williams, S. Tarawali, P. Hiernaux, and S. Fernandez-Rivera, 3-27. Wageningen, The Netherlands: CTA.

van der Jagt, P., and M. Abatcha. 1997. Une étude de la capacité de pâturage de la zone d'Abouli en vue de la création d'une forêt communautaire-Saison sèche 1996/1997. Maroua, Cameroon: Waza Logone Project (UICN).

Weber, G., J. Smith, and M.V. Manyong. 1996. System dynamics and the definition of research domains for the northern Guinea savanna of West Africa. Agriculture, Ecosystems and Environment 57 (2-3): 133-148.

Wilk, R.R., and L. Cliggett. 2007. Economies and cultures: Foundations of economic anthropology. Boulder, CO: Westview Press.

Williams, T.O., P. Hiernaux, and S. Fernández-Rivera. 1999. Croplivestock systems in sub-Saharan Africa: Determinants and intensification pathways. In Property rights, risk, and livestock development, ed. N. McCarthy, B. Swallow, M. Kirk, and P. Hazell, 132-151. Washington, DC: International Food Policy Research Institute.

\section{Author Biography}

Mark Moritz is an assistant professor in anthropology at the Ohio State University. His research focuses on the transformation of African pastoral systems. He has investigated how FulBe pastoralists in the Far North Province of Cameroon have adapted to changing ecological, political and institutional conditions that affect their lives and livelihoods. He continues to research herder-farmer conflicts, intensification of pastoral systems, and pastoral development. 